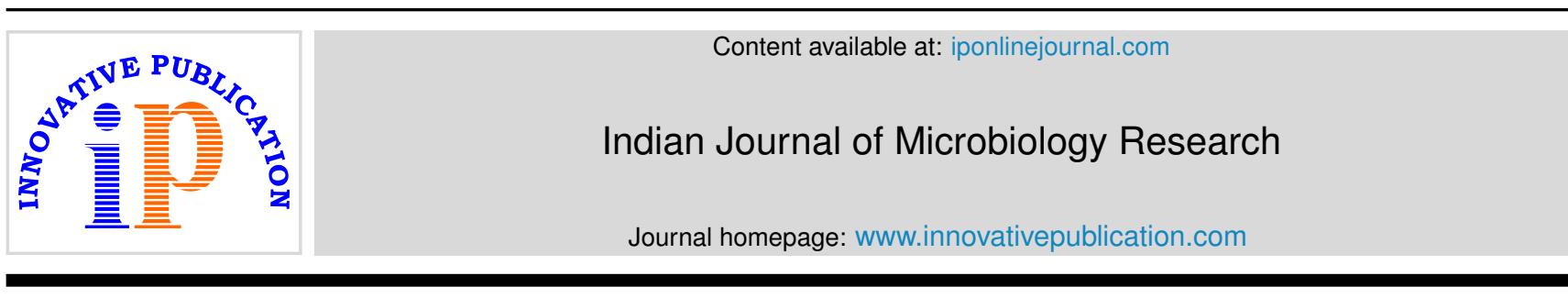

Original Research Article

\title{
Bacteriological profile of asymptomatic bacteriuria among pregnant women attending tertiary care hospital
}

\author{
Vijayalakshmi Arumugam1, Meerah Srinivasagam ${ }^{2, *}$, Sruthi Rajkannan $^{3}$ \\ ${ }^{1}$ Dept. of Microbiology, Chengalpattu Medical College, Chengalpattu, Tamil Nadu, India \\ ${ }^{2}$ Dept. of Microbiology, Government Sivagangai Medical College, Sivaganga, Tamil Nadu, India \\ ${ }^{3}$ Chengalpattu Medical College College in Tamil Nadu, Chengalpattu, Tamil Nadu, India
}

\section{A R T I C L E I N F O}

Article history:

Received 11-05-2019

Accepted 10-07-2019

Available online 09-09-2019

\section{Keywords:}

Asymptomatic bacteriuria (ASB)

Pregnant women

antenatal

Significant bacteriuria

Urinary tract infections (UTIs)

\begin{abstract}
A B S T R A C T
Introduction: Urinary tract infections (UTIs) are common in pregnancy. It is classified as Symptomatic bacteriuria \& Asymptomatic bacteriuria (ASB) based on clinical presentation. Failure to detect ASB causes increased risk for Mother and fetus.

Aim and Objectives: To study the prevalence, pathogens associated and antibiotic sensitivity pattern for the isolated pathogens causing significant bacteriuria among pregnant women without symptoms of urinary tract infection.

Results: Out of 240 urine samples, $12(5 \%)$ showed significant bacteriuria. Prevalence of culture positivity with respect to age was maximum between the age group of 25-30 (58.33\%). Prevalence of culture positivity among the trimesters, was high in the second trimester of pregnancy (75\%). Among the bacteria isolated, Escherichia coli was the most $(41.67 \%)$ followed by klebsiella pneumonia $(25 \%)$ and CoNS (16.67\%). Most of the isolates showed resistance to Cephalexin.

Materials and Methods: This prospective stud y will be conducted in a Tertiary Care Hospital for a period of 1 year with 240 Urine samples of pregnant women.

Conclusion: In this study, we would like to emphasize the importance of including urine culture as a routine antenatal screening test to avoid serious maternal and fetal complications.
\end{abstract}

(C) 2019 Published by Innovative Publication.

\section{Introduction}

Urinary tract infections (UTIs) in pregnancy is classified as Symptomatic bacteriuria \& Asymptomatic bacteriuria (ASB) based on clinical presentation. Asymptomatic bacteriuria (ASB) is a condition in which presence of minimum $10^{5}$ Colony forming units (CFU) per ml of clean catch midstream urine without symptoms and signs such as dysuria, frequency of micturition, fever, loin pains, renal angle tenderness, suprapubic pain and tenderness. ${ }^{1,2}$ The most common aetiological agent associated with both Symptomatic bacteriuria \& Asymptomatic bacteriuria is Escherichia coli ${ }^{3}$ which accounts for $70-80 \%$ of the isolates. In Pregnancy various physiological and anatomical changes leads to significant alterations in the Urinary tract. These

\footnotetext{
* Corresponding author.

E-mail address: meerahsethu@yahoo.co.in (M. Srinivasagam).
}

changes have a profound impact on the acquisition of bacteriuria. ${ }^{4}$ The risk of UTI may begin in $6^{\text {th }}$ week and will be at peak during $22-24^{\text {th }}$ weeks of pregnancy. ASB accounts for $2-11 \%$ in Pregnant women. ${ }^{5}$ Among them $20-50 \%$ can develop acute Pyelonephritis ${ }^{6,7}$ and it can lead to adverse obstetric outcomes as well, such as anaemia, hypertensive disease, prematurity, and higher foetal mortality rates if left untreated. Screening for asymptomatic bacteriuria has become a part of standard obstetric care these days and urine culturing is the Gold Standard screening technique for detecting the ASB which occurs during pregnancy. Failure to detect ASB causes increased risk for Mother and fetus.

Maternal complications include Pyeionephritis, Preeclampsia, endometritis, premature rupture of amniotic membrane, preterm labour and septicemia ${ }^{8} \mathrm{Fetal}$ complications includes abortion, low birth weight(LBW), 
Intra uterine growth retardation (IUGR) and even foetal death. $^{7,9-13}$ To ensure proper therapy, adequate knowledge of microorganisms that causes UTI and their Anti microbial susceptibility testing is required.

\section{Aim and Objectives}

1. To study the prevalence, pathogens associated and distribution of ASB with respect to age among antenatal mothers.

2. To determine the antibiotic sensitivity pattern for the isolated pathogens.

3. To emphasis the importance of early detection and to give guidance for the treatment and prevention of bacteruria in pregnant patients thereby aiding in the prevention of further complications.

\section{Materials and Methods}

This study will be conducted in Department of Microbiology and Obstetrics in a Tertiary Care Hospital. Ethical committee clearance was obtained from the Instituition and informed written consent was obtained from the antenatal mothers before collecting the specimen.

\subsection{Duration of study}

1 year (June 2017 to May 2018)

\subsection{Study design}

This is a prospective study.

\subsection{Study population}

Antenatal mothers.

\subsection{Sample size}

240 Urine samples.

\subsection{Inclusion criteria}

Antenatal women of all trimesters without any symptoms of UTI.

\subsection{Exclusion criteria}

1. Antenatal women with symptoms of UTI.

2. Antenatal women on antibiotics.

\subsection{Sample collection}

Before collecting urine sample the patients will be instructed to wash their hands and clean their genital area with soap and water and dry the area with sterile gauze pad.

Patients will then be asked to collect 10-20ml of Clean Catch Midstream Urine (CCMSU) in a sterile container and transport it immediately to the microbiological laboratory ${ }^{14,15}$

\subsection{Processing of sample}

All the collected urine samples will be microscopically examined for the presence of bacteria, RBC and pus cells by Gram stain and wet mount. Then they will be inoculated on to Cysteine Lactose Electrolyte Deficient agar and Blood agar plates and the plates will be incubated at 37 degree $\mathrm{C}$ for 18 to $24 \mathrm{hrs}$. Subsequently semi quantitative analysis will be done. A colony count of $10^{5}$ or more pure isolates will be processed for further identification. The isolates will be identified by standard biochemical tests. ${ }^{15}$

Table 1: Urine culture results $(\mathrm{n}=240)$

\begin{tabular}{lll}
\hline Culture & No.of samples & Percentage \\
Significant bacteriuria & 12 & $5 \%$ \\
Contamination & 5 & $2.1 \%$ \\
Sterile & 223 & $92.9 \%$ \\
\hline
\end{tabular}

Table 2: Prevalence of Culture positive samples according to age $(\mathrm{n}=12)$

\begin{tabular}{lll}
\hline AGE(years) & Culture positive samples & Percentage \\
$20-25$ & 4 & $33.33 \%$ \\
$25-30$ & 7 & $58.33 \%$ \\
$30-35$ & 1 & $8.33 \%$ \\
\hline
\end{tabular}

Table 3: Prevalence of culture positive samples according to trimesters of pregnancy $(n=12)$

\begin{tabular}{lll}
\hline Trimester & Culture Positive Samples & Percentage \\
First & 2 & $16.67 \%$ \\
Second & 9 & $75 \%$ \\
Third & 1 & $8.33 \%$ \\
\hline
\end{tabular}

Table 4: Bacterial isolates Detected $(n=12)$

\begin{tabular}{lll}
\hline Isolates & $\begin{array}{l}\text { Culture positive } \\
\text { Samples }\end{array}$ & Percentage \\
Escherichia coli & 5 & $41.67 \%$ \\
Klebsiella pneumoniae & 3 & $25 \%$ \\
Enterobacter aerogens & 1 & $8.33 \%$ \\
Staphylococcus aureus & 1 & $8.33 \%$ \\
CoNS(Coagulase & 2 & $16.67 \%$ \\
negative staphylococcus) & & \\
\hline
\end{tabular}

\section{Antibiotic sensitivity test}

The isolates are further tested for antibiotic sensitivity. Antimicrobial sensitivity testing (AST) will be carried out by using modified Kirby Bauer disc diffusion method.

The results will be interpreted in accordance with clinical laboratory standards institute's guidelines (CLSI- 2017). ${ }^{16}$ 
Table 5: Antimicrobial sensitivity pattern of the Isolates

\begin{tabular}{|c|c|c|c|c|c|c|c|c|c|c|}
\hline \multirow[t]{2}{*}{ Bacterial isolates } & \multicolumn{2}{|c|}{$\begin{array}{l}\text { Amoxycillin } \\
\text { (10ug) }\end{array}$} & \multicolumn{2}{|c|}{ Amoxy-Clav } & \multicolumn{2}{|c|}{$\begin{array}{l}\text { Cephalexin } \\
\text { (30ug) }\end{array}$} & \multicolumn{2}{|c|}{ Ceftriaxone } & \multicolumn{2}{|c|}{ Nitrofurantoin } \\
\hline & $\mathbf{S}$ & $\%$ & $\mathbf{S}$ & $\%$ & $\mathbf{S}$ & $\%$ & $\mathbf{S}$ & $\%$ & $\mathbf{S}$ & $\%$ \\
\hline Escherichia coli $(n=5)$ & 3 & 60 & 5 & 100 & 2 & 40 & 4 & 80 & 4 & 80 \\
\hline $\begin{array}{l}\text { Klebsiella pneumonia } \\
(\mathrm{n}=3)\end{array}$ & IR & - & 2 & 66 & 1 & 33 & 3 & 100 & 3 & 100 \\
\hline $\begin{array}{l}\text { Enterobacter aerogens } \\
(n=1)\end{array}$ & IR & - & IR & - & IR & - & 1 & 100 & 1 & 100 \\
\hline $\begin{array}{l}\text { Staphylococcus aureus } \\
(\mathrm{n}=1)\end{array}$ & 1 & 100 & 1 & 100 & 1 & 100 & 1 & 100 & 1 & 100 \\
\hline CoNS $(n=2)$ & 1 & 50 & 1 & 50 & 1 & 50 & 1 & 50 & 2 & 100 \\
\hline
\end{tabular}

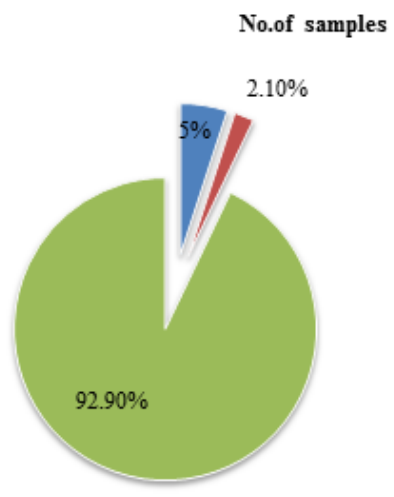

- Significant bacteriuria

- Contamination

Iterile

Fig. 1: Urine culture results $(\mathrm{n}=240)$

\section{Prevalence of Culture positive samples according to age}

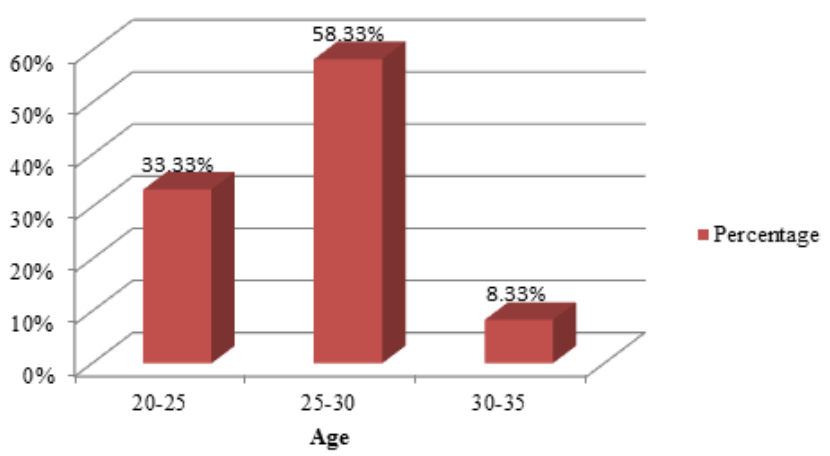

Fig. 2: Prevalence of Culture positive samples according toage $(n=12)$

\section{Results}

Out of 240 urine samples, 12(5\%) showed significant bacteriuria. Prevalence of culture positivity with respect to age was maximum between the age group of 25-30 $(58.33 \%)$. Prevalence of culture positivity among the trimester s of pregnancy was high in the second trimester (75\%). Among the bacteria isolated, Escherichia coli was the most (41.67\%) followed by klebsiella pneumonia (25\%)

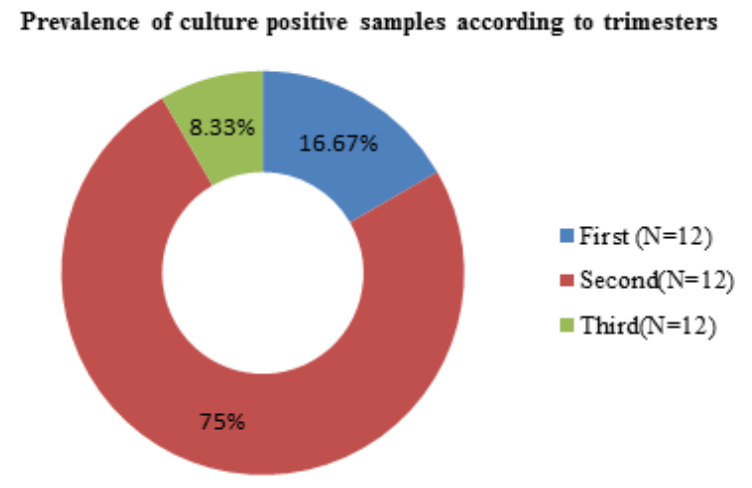

Fig. 3: Prevalence of culturepositive samples according to trimesters of Pregnancy $(n=12)$

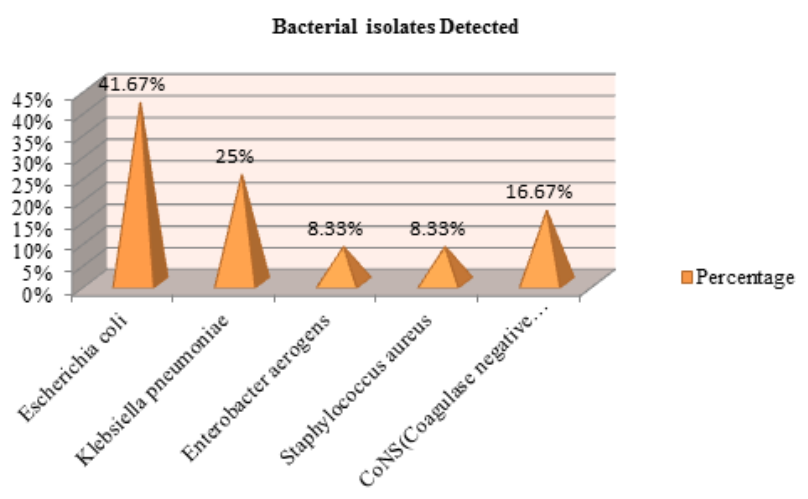

Fig. 4: Bacterial isolates detected $(n=12)$

and CoNS (16.67\%). Most of the isolates showed resistance to cephalexin.

\section{Discussion}

$\mathrm{T}$ he prevalence of Asymptomatic bacteriuria (ASB) in this study was found to be $5 \%$, this correlates with some other studies, which have shown the prevalence between 5 and $12 \% .{ }^{17-20}$ Various reports across the world have 
documented a prevalence of as high as 40 to $45 \%{ }^{6,10}$ In this study higher incidence of ASB was reported in $2^{\text {nd }}$ trimester. This correlates with studies done by. ${ }^{21}$ The common pathogen isolated was Escherichia coli followed by Klebsiella species. This correlates with other studies done by. ${ }^{10,19,22-27}$ The most preferred antibiotics for ASB are Amoxicillin, Cephalexin, Amoxy-clav, Ceftriaxone and nitrofurantoin. But it is advised that nitrofurantoin should not be given after 36 weeks of pregnancy. Antimicrobial susceptibility testing showed, Cephalexin was resistance in most of the isolates and $100 \%$ sensitivity towards Nitrofurantoin was seen in most of the isolates. Among the CoNS, one of the isolate was Methicillin Resistant but showed sensitivity to Nitrofurantoin. All the antibiotics should be given for seven days to ensure complete cure. ${ }^{28}$ Urine culture should be repeated after completion of treatment to ensure complete eradication of pathogen. ${ }^{29-31}$

\section{Conclusion}

In this study, we would like to emphasize the importance of including urine culture as a routine antenatal screening test to avoid serious maternal and fetal complications.

\section{Source of Funding}

None.

\section{Conflict of Interest}

None.

\section{References}

1. Anantanarayana R, Paniker J ;. 9th Ed pg-670.

2. Vaghela GH, Hitesh R. Ahir Bacteriological profile and anti-biogram pattern of asymptomatic UTI in pregnant Women at Tertiary Care Teaching Hospital. Vadodara,Gujarat ;.

3. Enayat K, Fariba F, Bahram N. Asymptomatic bacteriuria among pregnant women referred to out-patient clinics in Sanandaj, Iran. Int Braz J Urol. 2008;34:699-707.

4. Jeyabalan A, Lain KY. Anatomic and functional changes of the upper urinary tract during pregnancy. Urol Clin North. 2007;34:1-6.

5. Prasanna B, Naimisha M, Swathi K, and VMS. Pregnant Women, Isolates and their Culture Sensitivity Pattern. Int J Curr Microbiol App Sci . 2015;4(8):28-35.

6. Urinary Tract Infections in Pregnancy ; 2016,. .

7. Schnarr J, Smaill F. Asymptomatic bacteriuria and symptomatic urinary tract infections in pregnancy. Eur J Clin Invest. 2008;

8. Kasinathan A, Thirumal P. Prevalence of asymptomatic bacteriuria in antenatal women attending a tertiary care hospital. Int $J$ Reprod Contracept Obstet Gynecol. 2014;3(2):437-441.

9. Cunningham FG, Gant NF, Laveno KJ. Renal and urinary tract disorders. WO, editor. New York: McGraw-Hill Medical Publishing Division ; 2001,. 21 st ed.

10. Delzell JE, Lefevre ML. Urinary tract infections during pregnancy. Am Family Physician. 2000;61(3):713-34

11. Hamdan Z, Haliem HA, Ziad M, Ali SK, AI. Epidemiology of urinary tract infections and antibiotics sensitivity among pregnant women at Khartoum North hospital. Ann Clin Microbiol Antimicrob. 2011;10(2).
12. EH K. Pyelonephritis and bacteriuria. A major problem in preventive medicine. Ann Intern Med. 1962;65(1):46-53.

13. Lin K, Fajardo K ; 2008,.

14. Tille P. Bailey \& Scott's Diagnostic Microbiology ; 2013,.

15. Cheesbrough M. District Laboratory Practice in Tropical Countries, Part 2 ;. p. 113-4.

16. Performance standards for Antimicrobial Susceptibility testing, $23 \mathrm{rd}$ information supplement-CLSI. ; 2016,. p. 100-123.

17. Gayathree I, Shetty S, Deshpande SR, Venkatesh DT. Screening for asymptomatic bacteriuria in pregnancy. An evaluation of various screening tests in Hassan district hospital, India. J Clin Diag Res. 2010;4:2702-2708.

18. Kriplani A, Buksheek K, Ratan A. Asymptomatic bacteriuria in pregnant Indian patients at all india institute of medical sciences, New Delhi and treatment with single dose antimicrobial therapy. J Obstet Gynaecol India. 1993;43:489-91.

19. Lavanya SV, Jogalokshmi D. Asymptomatic bacteriuria in antenatal women. Int J Med Microbiol. 2002;20:105-111.

20. Yashodhara P, Mathur R, Raman I. Urinary tract infection in pregnancy. Indian J Med Res. 1987;86:309-23.

21. Ajayi AB, Nwabuisi C, Aboyeji AP, Ajayi NS, Fowotade A, et al. Asymptomatic bacteriuria in antenatal patients in Ilorin, Nigeria. Oman Med J. 2012;27(1).

22. LR C, A K, A K. Prevalence of pregnancy associated bacteriuria: a study done in a tertiary care hospital. J Obstet Gynaecol India. 2012;62:511-515.

23. Kerure SB, Surpur R, Sagarad SS, Hegadi S. Asymptomatic bacteriuria among pregnant women. Int J Reprod Contracept Obstet Gynaecol. 2014;2(2):213-219.

24. Nair RM, Macdonald SR, Dooley SL. Evaluation of the centrifuged and gram-stained smear urinalysis and reagent strip testing to detect asymptomatic bacteriuria in Obstetric patients. Am J Obstet Gynaecol. 2000;182:1076-1085.

25. Shankar RD, Arlappa N. An updated Prasads socioeconomic status classification for 2013. Int J Res Dev Health. 2013;1(2):26-34.

26. Senthinath TJ, Rajalaksmi PC, Keerthana R, Vigneshwari RS, Revathi P. Prevalence of asymptomatic bacteriuria among antenatal women in rural tertiary care hospital, Tamil Nadu, India ; 2013,

27. -. Int J Curr Microbiol App Sci. 2013;2(1):80-85. rural tertiary care hospital.

28. Lumbiganon P, Villar J, Laopaiboon M. One- day compared with 7-day nitrofurantoin for asymptomatic bacteriuria in pregnancy: a randomized controlled trial. Obstet Gynecol. 2009;113:339.

29. Clinical Knowledge Summaries (CKS). cited. Available from ; 2009,

30. Urinary tract infections in women:Diagnosis and management in primary care BMJ. vol. $332 ; 2006,$.

31. Management of urinary tract infections in Pregnancy.institute of Obstetrician and Gynaecologist,royal college of Physicians of Ireland. Practice Guideline. 2015;332. Publication date.

\section{Author biography}

Vijayalakshmi Arumugam Professor

Meerah Srinivasagam Assistant Professor

Sruthi Rajkannan Final MBBS Student

Cite this article: Arumugam V, Srinivasagam M, Rajkannan S.

Bacteriological profile of asymptomatic bacteriuria among pregnant women attending tertiary care hospital. Indian J Microbiol Res 2019;6(3):229-232. 